\title{
AKRUAL
}

Jurnal Akuntansi

http://fe.unesa.ac.id/ojs/index.php/akrl

\section{MANAJEMEN MODAL KERJA DAN DAMPAKNYA TERHADAP NILAI PERUSAHAAN DENGAN CORPORATE GOVERNANCE SEBAGAI VARIABEL PEMODERASI}

\author{
Adrianus Dhimas Setyanto \\ Ika Permatasari \\ Universitas Negeri Surabaya \\ Email: permatasari1980@gmail.com
}

Artikel diterima: 17 Juni 2015

Terakhir direvisi: 01 Juli 2015

\begin{abstract}
This study aims to determine the effect of working capital management on firm value. Corporate governance is used as a moderating variable in this study to explore the role of corporate governance in the relationship between working capital management with corporate values. Program participants of Corporate Governance Perception Index (CGPI) are used as a sample during the period from 2003 to 2011 and listed on the Indonesian Stock Exchange (IDX). We were using simple linear regression and the testing of moderating effects were calculated by Moderated Regression Analysis (MRA). The results showed that the working capital management has an influence on the value of the firm. However, corporate governance variables failed to moderate the relationship between working capital management and enterprise value. It shows that companies and investors in the market still lack concern for the program response and Corporate Governance Perception Index (CGPI) as an assessment of the application of the principles of corporate governance that has been done by the company.
\end{abstract}

Keywords: Working Capital Management, Cash Conversion Cycle, Corporate Governance, Firm Values

\section{PENDAHULUAN}

Tata kelola perusahaan menyangkut banyak aspek dalam perusahaan terutama mengenai manajemen terhadap sumber daya yang dimiliki oleh perusahaan. Salah satu sumber daya yang dimiliki perusahaan tersebut adalah modal kerja (working capital) yang mana meliputi penerimaan (receivables), persediaan (inventory), utang usaha (payables), dan pemakaian kas secara efisien untuk kegiatan operasional harian perusahaan. Optimalisasi modal kerja yang dilakukan melalui tata kelola perusahaan dapat meminimalkan biaya pengelolaan modal kerja dan pada akhirnya dapat meningkatkan free cash flow perusahaan (Ganesan, 2007).

Adanya tata kelola perusahaan yang baik akan mengakibatkan kebijakan yang diambil dalam manajemen modal kerja menjadi semakin efektif dan efisien. Sebaliknya, inefisiensi dalam kebijakan manajemen modal kerja disebabkan oleh adanya tata kelola perusahaan yang lemah dan pada akhirnya hal itu akan 
mengakibatkan dampak negatif bagi kemakmuran pemegang saham. Harford et al. (2008) dalam penelitiannya juga mengemukakan bahwa tata kelola perusahaan yang lemah akan berakibat kurang baik pada manajemen kas, piutang usaha, persediaan, utang usaha, dan siklus konversi kas perusahaan.

Penerapan prinsip tata kelola perusahaan yang baik secara konsisten juga akan dapat meningkatkan kinerja dan nilai perusahaan yang pada akhirnya juga akan meningkatkan kemakmuran para pemegang saham perusahaan. Nilai perusahaan (enterprise value atau juga dikenal sebagai firm value) merupakan suatu konsep yang penting bagi investor, karena merupakan indikator bagi investor di pasar dalam menilai perusahaan secara keseluruhan. Hal itu dikarenakan nilai perusahaan dapat memberikan kemakmuran pemegang saham secara maksimum apabila harga saham meningkat. Semakin tinggi harga saham sebuah perusahaan, maka makin tinggi kemakmuran pemegang saham.

Black et al. (2005) yang melakukan penelitian terhadap hubungan antara corporate governance dan nilai pasar perusahaan pada perusahaan-perusahaan di Rusia selama periode 1999-2005 membuktikan bahwa pengukuran corporate governance pada level perusahaan berhasil memprediksikan harga saham yang lebih tinggi dan mereka juga menyimpulkan bahwa penerapan corporate governance memiliki pengaruh yang kuat terhadap nilai pasar perusahaan baik secara statistik maupun secara ekonomi. Corporate governance juga merupakan salah satu faktor penting yang dapat menjelaskan nilai perusahaan-perusahaan publik. Black et al. (2006) dalam penelitiannya di Korea telah memberikan bukti bahwa perusahaan-perusahaan publik yang menggunakan kebijakan pengelolaan perusahaan yang baik akan memiliki nilai perusahaan yang lebih tinggi.

Beberapa penelitian yang terkait dengan hubungan manajemen modal kerja dengan nilai perusahaan telah dilakukan oleh para peneliti sebelumnya. Bandara dan Banda (2011) menguji dampak penerapan manajemen modal kerja terhadap nilai perusahaan pada perusahaan-perusahaan yang tercatat dalam Bursa Saham Kolombo, Sri Lanka. Hasil penelitiannya menemukan bahwa ketika perusahaan menerapkan kebijakan manajemen modal kerja konservatif, Market Value Added (MVA) akan mengalami peningkatan. Sementara itu nilai Economic Value Added (EVA) akan menurun pada saat perusahaan menerapkan kebijakan manajemen modal kerja agresif dan ketika perusahaan menerapkan kebijakan manajemen modal kerja moderat maka akan meningkatkan MVA dan EVA secara bersama-sama.

Ogundipe et. al. (2012) melakukan penelitian pada seluruh perusahaan yang tercatat di Bursa Saham Nigeria untuk menemukan dampak manajemen modal kerja terhadap profitabilitas dan nilai pasar perusahaan melalui analisis korelasional dan regresi berganda. Dalam penelitian tersebut ditemukan bahwa manajemen modal kerja yang diproksikan melalui siklus konversi kas (cash conversion cycle) mempunyai hubungan yang signifikan positif terhadap nilai pasar perusahaan dan signifikan negatif pada profitabilitas perusahaan. Hal tersebut menunjukkan bahwa perusahaan-perusahaan di Nigeria telah melakukan manajemen modal kerja yang efisien terutama manajemen terhadap komponen siklus konversi kas sehingga nilai pasar perusahaan akan meningkat.

Sementara itu hasil yang berbeda ditemukan di dalam penelitian Azhar dan Noriza (2011). Di dalam penelitiannya pada Bursa Saham Malaysia selama kurun 
waktu 2003-2007 untuk menemukan bukti empiris mengenai penerapan manajemen modal kerja pada profitabilitas dan nilai pasar perusahaan, mereka menemukan bahwa manajemen modal kerja memiliki hubungan negatif terhadap profitabilitas dan nilai perusahaan. Meskipun demikian, hal itu tetap menunjukkan bahwa manajemen modal kerja memiliki peran dalam profitabilitas dan nilai pasar perusahaan. Azhar dan Noriza (2011) juga berpendapat bahwa manajemen modal kerja juga semestinya merupakan bagian yang tidak terpisahkan dalam pola pikir strategi operasional perusahaan dalam tujuannya untuk mencapai efektivitas dan efisiensi pengelolaan perusahaan.

Lemahnya tingkat penerapan tata kelola perusahaan di Indonesia mengakibatkan terjadinya beberapa masalah pada perusahaan-perusahaan pemerintah maupun swasta. Beberapa kasus tersebut di antaranya adalah kasus pengadaan alat sistem informasi induk (CIS-RISI) pada PT. PLN (Persero) area Jakarta Jaya, Tangerang dan Lampung, serta adanya kasus manipulasi informasi keuangan pada PT. Kimia Farma Tbk. dan PT. Lippo Bank Tbk. Kasus-kasus tersebut terjadi karena masih lemahnya tata kelola perusahaan oleh manajemen dan adanya tindakan oportunis manajer dalam mengelola sumber daya yang dimiliki perusahaan. Peningkatan penerapan tata kelola perusahaan yang baik menjadi mutlak dilakukan oleh perusahaan-perusahaan setelah terjadinya beberapa kasus tersebut. Hal itu ditandai dengan berdirinya beberapa organisasi yang bertujuan untuk mendorong penerapan tingkat tata kelola perusahaan yang baik guna mengurangi tindakan oportunis manajer perusahaan, seperti Komite Nasional Kebijakan Governance (KNKG), Forum for Corporate Governance Indonesia (FCGI), dan The Indonesian Institute for Corporate Governance (IICG).

Pengukuran tingkat penerapan corporate governance di samping menggunakan mekanisme internal dan eksternal, juga dapat dilakukan dengan berdasarkan pada corporate governance index. Indeks tersebut merupakan hasil penilaian para ahli terhadap implementasi dari beberapa komponen mekanisme corporate governance yang telah dijalankan oleh perusahaan. Dalam penelitian ini, tingkat penerapan corporate governance pada perusahaan-perusahaan sampel akan diukur dengan menggunakan corporate governance index yang pengukurannya telah dilakukan oleh The Indonesian Institute for Corporate Governance (IICG). Ini dikarenakan corporate governance index merupakan ukuran implementasi corporate governance yang dapat dipercaya oleh sebagian besar investor di pasar modal. Beberapa ahli juga telah mengungkapkan bahwa dengan melalui corporate governance index dapat diketahui adanya hubungan yang positif dan signifikan antara corporate governance dengan kinerja maupun nilai perusahaan (Black, 2001; Klapper dan Love, 2002; Black et al., 2005).

Sementara itu dalam penelitian ini manajemen modal kerja diukur dengan siklus konversi kas (cash conversion cycle). Manajemen modal kerja yang diukur melalui siklus konversi kas menarik untuk diteliti karena pemilihan siklus konversi kas yang digunakan akan dapat meningkatkan dan juga menurunkan profitabilitas dan nilai perusahaan perusahaan. Hal itu dikarenakan siklus konversi kas yang panjang akan meningkatkan penjualan perusahaan yang pada akhirnya akan meningkatkan profitabilitas perusahaan. Akan tetapi apabila biaya yang harus dikorbankan perusahaan dalam berinvestasi pada modal kerja tumbuh lebih cepat daripada keuntungan yang diperoleh dengan menahan lebih banyak 
persediaan dan piutang usaha, maka perusahaan akan mengalami penurunan profitabilitas (Deloof, 2003).

Berbeda dengan penelitian sebelumnya, penelitian ini akan mencoba memposisikan corporate governance sebagai variabel yang memoderasi hubungan antara manajemen modal kerja pada nilai perusahaan. Hal itu dikarenakan corporate governance merupakan salah satu komponen yang berperan penting dan berpengaruh terhadap pengelolaan sumber daya perusahaan guna mencapai nilai perusahaan yang maksimal. Melalui adanya penerapan tata kelola perusahaan yang baik (good corporate governance) tersebut diharapkan juga akan memperkuat manajemen modal kerja perusahaan sehingga pada akhirnya, manajer melalui kebijakan-kebijakannya yang terkait dengan modal kerja dapat meningkatkan profitabilitas dan nilai perusahaan. Berdasarkan beberapa uraian tersebut, maka penelitian bertujuan untuk menganalisis dampak manajemen modal kerja terhadap nilai perusahaan dengan corporate governance sebagai variabel pemoderasi yang dapat memperkuat atau memperlemah hubungan antara manajemen modal kerja dan nilai perusahaan tersebut.

\section{KAJIAN PUSTAKA \\ Manajemen Modal Kerja}

Modal kerja merupakan satu komponen yang sangat penting bagi perusahaan. Modal kerja pada dasarnya adalah bagian dari aset lancar perusahaan yang relatif lebih likuid dan mempunyai karakteristik: 1) berjangka waktu pendek, biasanya kurang dari satu tahun; 2) mudah diubah ke dalam bentuk aset-aset lancar yang lain; dan 3) jumlah modal kerja tergantung dari sinkronisasi antara waktu produksi, penjualan dan penagihan piutang.

Manajemen modal kerja sering kali diukur dengan menggunakan siklus konversi kas (cash conversion cycle). Siklus konversi kas mencerminkan interval waktu bersih antara biaya aktual kas pada saat perusahaan melakukan pembelanjaan sumber daya produktif dengan waktu terakhir perusahaan menerima kas yang berasal dari penjualan produk. Secara singkat dapat pula dikatakan bahwa siklus konversi kas merupakan lamanya waktu atau periode yang dibutuhkan untuk mengkonversi setiap kas yang dikeluarkan menjadi aliran kas masuk dalam kegiatan operasional perusahaan sehari-hari (Verlyn dan Laughlin, 1980).

Perspektif siklus konversi kas merupakan salah satu dasar yang dapat digunakan oleh pihak perusahaan dalam rangka memengaruhi profitabilitas maupun likuiditas perusahaan. Hal itu dikarenakan setiap kebijakan yang terkait dengan siklus konversi kas akan memiliki dampak yang positif atau negatif terhadap profitabilitas dan likuiditas perusahaan. Pada saat perusahaan memilih siklus konversi kas yang singkat, maka perusahaan akan mempercepat periode penjualan persediaan barang dagangan dan penagihan piutang kepada pelanggan dalam rangka menurunkan periode konversi persediaan dan periode piutang.

\section{Nilai Perusahaan}

Nilai perusahaan merupakan salah satu komponen penting yang banyak digunakan oleh para investor di pasar modal sebagai dasar investasi mereka. Beberapa konsep nilai yang dapat menjelaskan nilai suatu perusahaan adalah nilai 
nominal, nilai pasar, nilai intrinsik, nilai buku dan nilai likuidasi. Nilai perusahaan secara tidak langsung dapat mencerminkan kesejahteraan pemegang saham dalam perusahaan. Sudana (2011: 16) berpendapat bahwa semakin tinggi nilai perusahaan dapat menggambarkan tingkat kesejahteraan yang tinggi dari pemegang saham perusahaan, sehingga mempertahankan nilai perusahaan yang baik dalam perusahaan yang telah go public menjadi suatu hal yang sangat penting.

Pengukuran nilai perusahaan dapat dilakukan dengan menggunakan beberapa ukuran atau indikator, di mana salah satunya adalah dengan menggunakan rasio Tobin's $Q$. Melalui rasio Tobin's $Q$ tersebut informasi mengenai nilai perusahaan dapat diungkapkan dengan lebih baik karena rasio tersebut menjelaskan berbagai macam fenomena yang terjadi dalam kegiatan operasional perusahaan, misalnya seperti hubungan antara kepemilikan saham manajerial dengan nilai perusahaan, hubungan antara kinerja manajemen dengan profitabilitas maupun kebijakan-kebijakan yang terkait dengan pendanaan, keputusan investasi, dividen, dan kompensasi.

\section{Manajemen Modal Kerja dan Nilai Perusahaan}

Teori yang dikemukakan oleh Modigliani dan Miller menyatakan bahwa nilai perusahaan ditentukan oleh earnings power dari aset perusahaan. Semakin tinggi earnings power maka akan semakin efisien perputaran aset dan semakin tinggi profit margin yang diperoleh perusahaan. Hal itu tentu akan memiliki dampak terhadap nilai perusahaan. Nilai perusahaan terdiri dari nilai utang dan nilai saham perusahaan, sehingga pada saat harga saham naik maka akan mencerminkan pula adanya kenaikan pada nilai perusahaan.

Penelitian terkait pengaruh manajemen modal kerja terhadap nilai perusahaan telah dilakukan oleh para peneliti. Azhar dan Noriza (2010) melakukan penelitian secara acak pada 172 perusahaan yang terdaftar di Bursa Saham Malaysia selama kurun waktu 2003-2007 guna menemukan bukti empiris mengenai penerapan manajemen modal kerja pada profitabilitas dan nilai pasar perusahaan. Manajemen modal kerja diukur dengan menggunakan siklus konversi kas, current ratio (CR), current asset to total asset ratio (CATAR), current liabilities to total asset ratio (CLTAR), dan debt to asset ratio (DTAR) sedangkan nilai perusahaan diukur dengan menggunakan Tobin's Q. Mereka menemukan hubungan negatif antara variabel manajemen modal kerja dengan profitabilitas dan nilai perusahaan. Meskipun demikian, hal itu tetap menunjukkan bahwa manajemen modal kerja memiliki arti yang penting dalam peningkatan profitabilitas dan nilai pasar perusahaan. Di samping itu, manajemen modal kerja juga semestinya merupakan bagian yang tidak terpisahkan dalam pola pikir strategi operasional perusahaan dalam tujuannya untuk mencapai efektivitas dan efisiensi pengelolaan perusahaan.

Bandara dan Banda (2011) menguji dampak penerapan manajemen modal kerja terhadap nilai perusahaan pada 74 perusahaan yang tercatat dalam Bursa Saham Kolombo di mana meliputi tujuh sektor usaha yang berbeda selama periode 2005-2009. Analisis regresi panel digunakan untuk mengetahui hubungan antara penerapan manajemen modal kerja agresif, moderat, dan konservatif dengan nilai perusahaan (MVA dan EVA). Dalam penelitian tersebut mereka 
berhasil menemukan bahwa ketika perusahaan menerapkan kebijakan manajemen modal kerja konservatif, Market Value Added (MVA) akan mengalami peningkatan. Sementara itu nilai Economic Value Added (EVA) akan menurun pada saat perusahaan menerapkan kebijakan manajemen modal kerja agresif dan ketika perusahaan menerapkan kebijakan manajemen modal kerja moderat maka akan meningkatkan MVA dan EVA secara bersama-sama.

Ogundipe et al. (2012) melakukan penelitian pada 54 perusahaan non finansial yang terdaftar pada Bursa Efek Nigeria (NSE) selama kurun waktu 1995-2009 untuk menemukan hubungan antara manajemen modal kerja dengan kinerja perusahaan dan nilai pasar perusahaan. Hasil penelitian menunjukkan terdapat hubungan negatif antara ketiga variabel tersebut. Hubungan yang positif hanya ditemukan pada hubungan antara rasio utang terhadap nilai pasar perusahaan. Hal itu menunjukkan bahwa komponen-komponen dari modal kerja dapat memberikan kontribusi dalam meningkatkan nilai pasar perusahaan sehingga manajer perlu melakukan manajemen yang baik terhadap modal kerja yang dimiliki perusahaan. Berdasarkan beberapa uraian tersebut, maka hipotesis yang dapat dibuat dalam penelitian ini adalah:

\section{$\mathrm{H}_{1}$ : Manajemen modal kerja mempunyai pengaruh terhadap nilai perusahaan.}

\section{Corporate Governance}

Pada dasarnya corporate governance adalah suatu konsep yang muncul akibat dari adanya konflik keagenan dalam perusahaan yang melibatkan pemilik perusahaan (prinsipal) dengan manajemen perusahaan (agen). Corporate governance merupakan suatu prosedur dalam perusahaan yang dibuat untuk tujuan memberikan suatu wewenang kepada direksi dalam menginformasikan keadaan yang sesungguhnya dari investor dan stakeholder lainnya dan sekaligus memberikan wewenang kepada direksi untuk membuat kebijakan-kebijakan yang efektif dan efisien yang berkaitan dengan perusahaan.

Dalam penelitian ini Corporate Governance diukur melalui indeks Corporate Governance yang diperoleh melalui program Corporate Governance Perception Index (CGPI) yang diselenggarakan oleh The Indonesian Institute for Corporate Governance (IICG). Corporate Governance Perception Index (CGPI) adalah suatu program pemeringkatan penerapan Good Corporate Governance (GCG) pada perusahaan-perusahaan di Indonesia melalui riset yang dirancang untuk mendorong perusahaan meningkatkan kualitas penerapan konsep Corporate Governance (CG) melalui perbaikan yang berkesinambungan (continuous improvement) dengan melaksanakan evaluasi dan melakukan suatu titik banding (benchmarking).

\section{Manajemen Modal Kerja dan Nilai Perusahaan}

Implementasi prinsip-prinsip good corporate governance menyangkut berbagai macam aspek dalam perusahaan, tidak hanya berpusat pada hubungan antara manajer dan pemilik perusahaan tetapi juga pada pengelolaan terhadap sumbersumber daya yang dimiliki perusahaan dalam tujuannya untuk mencapai kemakmuran yang diinginkan para pemegang saham. Beberapa penelitian yang mengungkapkan dampak corporate governance pada nilai perusahaan telah 
dilakukan oleh para peneliti. Sebagian besar penelitian yang dilakukan menghasilkan satu kesimpulan yang sama yaitu bahwa penerapan corporate governance memiliki dampak yang positif terhadap harga saham dan nilai perusahaan di pasar (Black, 2001; Black et al., 2005; Black et al., 2006; Bauer et al., 2003; dan Gill dan Obradovich, 2012). Investor masih memiliki kepercayaan terhadap nilai perusahaan dan mereka mempertimbangkan hal tersebut sebagai salah satu dasar yang kuat dalam melakukan investasi.

Gill dan Biger (2013) yang mengeksplorasi dampak corporate governance terhadap efisiensi manajemen modal kerja pada 42 perusahaan manufaktur di Kanada selama periode 2009-2011 menemukan bahwa corporate governance yang diukur dengan lama jabatan CEO (CEO Tenure) dan CEO duality akan memengaruhi tingkat efisiensi manajemen modal kerja. Hasil penelitian itu dapat mencerminkan bahwa semakin lama jabatan seorang CEO maka akan memiliki semakin banyak pengalaman dalam manajemen modal kerja perusahaan, sehingga CEO yang telah memiliki banyak pengalaman dapat membuat kebijakankebijakan terbaik guna meningkatkan efisiensi manajemen modal kerja yang dimiliki perusahaan.

Sementara itu, Ergin (2012) dalam penelitiannya pada perusahaanperusahaan yang terdaftar dalam Bursa Efek Turki (ISE) menemukan bahwa corporate governance ratings digunakan oleh para investor dalam mengevaluasi kinerja saham perusahaan di pasar sebagai dasar investasi mereka. Meskipun corporate governance ratings merupakan regulasi baru di negara Turki, akan tetapi hal itu telah mampu memengaruhi pandangan investor di pasar sehingga juga akan berdampak secara langsung pada kapitalisasi pasar. Di samping itu, ia juga menemukan bahwa corporate governance ratings akan berdampak pada kinerja akuntansi yaitu ekuitas pemegang saham dan laba bersih perusahaan. Hal itu menunjukkan bahwa komponen-komponen dalam corporate governance ratings akan mempunyai pengaruh yang positif terhadap kinerja keuangan perusahaan dan nilai pasar perusahaan.

Konsep good corporate governance mensyaratkan adanya tata kelola perusahaan yang baik. Tata kelola perusahaan yang baik tersebut akan mencerminkan langkah-langkah yang dilakukan manajemen dalam mengelola aset dan modal perusahaan dengan baik guna menarik minat dan memperoleh kepercayaan para investor di pasar. Keberhasilan manajer dalam pengelolaan aset dan modal suatu perusahaan salah satunya dapat dilihat dari nilai pasar perusahaan tersebut di mata investor. Apabila pengelolaan aset dan modal dilakukan dengan baik oleh manajer, maka secara otomatis juga akan meningkatkan nilai perusahaan di pasar. Berdasarkan beberapa uraian tersebut, maka hipotesis yang dapat dibuat dalam penelitian ini adalah:

$\mathrm{H}_{2}$ : Corporate governance mampu memoderasi pengaruh manajemen modal kerja terhadap nilai perusahaan.

\section{METODE PENELITIAN}

\section{Pemilihan Sampel}

Sampel yang digunakan dalam penelitian ini adalah perusahaan peserta program CGPI yang terdaftar dalam Bursa Efek Indonesia (BEI) yang diambil dengan 
menggunakan metode purposive sampling. Adapun kriteria sampel yang akan digunakan yaitu:

\section{Kriteria}

Jumlah

1) Perusahaan sampel merupakan perusahaan yang terdaftar 153 di Bursa Efek Indonesia (BEI) dan mengikuti program Corporate Governance Perception Index (CGPI) yang dilakukan oleh The Indonesian Institute for Corporate Governance (IICG).

2) Perusahaan sampel adalah perusahaan non keuangan.

3) Tersedia laporan keuangan perusahaan secara lengkap

\section{selama tahun 2003-2011.
Total Sampel \\ selama tahun 2003-2011.
Total Sampel}

\section{Variabel Dependen}

Nilai perusahaan merupakan suatu rasio yang menggambarkan seberapa besar penilaian investor pada nilai pasar ekuitas terhadap nilai buku ekuitas perusahaan atau dapat pula dikatakan sebagai seberapa besar pasar menghargai nilai buku saham pada suatu perusahaan. Nilai perusahaan yang semakin tinggi berarti pasar percaya akan prospek perusahaan tersebut. Nilai perusahaan (firm value) pada penelitian ini diukur dengan menggunakan nilai rasio Tobin's $Q$.

Herawaty (2008) juga mengungkapkan bahwa apabila nilai rasio Tobin's $Q$ di atas satu (Q>1), maka investasi dalam aset akan menghasilkan laba yang lebih tinggi daripada pengeluaran investasinya sehingga hal itu akan merangsang perusahaan melakukan investasi baru. Sebaliknya apabila nilai rasio Tobin's $Q$ di bawah satu $(\mathrm{Q}<1)$ maka investasi perusahaan dalam aset menjadi kurang efektif dan efisien. Pengukuran rasio Tobin's $Q$ dilakukan dengan rumus berikut:

di mana:

$$
\text { Tobin's } Q=\frac{M V E+D}{B V E+D}
$$

$\begin{array}{lll}\text { Tobin's Q } & = & \text { Nilai perusahaan } \\ \text { MVE } & = & \text { Nilai pasar ekuitas (Equity Market Value) } \\ \mathrm{D} & = & \text { Nilai buku dari total hutang } \\ \text { BVE } & = & \text { Nilai buku dari ekuitas (Book Value Equity) }\end{array}$

\section{Variabel Independen}

Variabel independen dalam penelitian ini adalah manajemen modal kerja (working capital management). Manajemen modal kerja dalam penelitian ini diukur dengan menggunakan siklus konversi kas (cash conversion cycle/CCC) perusahaan. Siklus konversi kas merupakan suatu ukuran yang banyak digunakan sebagai pengukur manajemen modal kerja karena dalam siklus konversi kas diperhitungkan pula komponen-komponen modal kerja, yaitu persediaan, piutang usaha, dan utang usaha. Perhitungan siklus konversi kas dalam penelitian ini merujuk pada rumus yang digunakan oleh Deloof (2003) dan Gill dan Biger (2013) yaitu sebagai berikut:

Siklus konversi kas $=($ periode piutang + periode persediaan $)-$ periode utang usaha 
dimana:

$$
\text { Periode Piutang }=\frac{\text { Piutang Usaha }}{\text { Penjualan Tahunan }} \times 365
$$

\section{Periode Persediaan}

$$
=\frac{\text { Persediaan }}{\text { Harga Pokok Penjualan tahunan }} \times 365
$$

\section{Periode Utang Usaha}

$$
=\frac{\text { Utang Usaha }}{\text { Harga Pokok Penjualan tahunan }} \times 365
$$

\section{Variabel Pemoderasi}

Peneliti menggunakan corporate governance sebagai variabel pemoderasi dalam penelitian ini. Variabel tersebut diukur dengan menggunakan skor GCG pada laporan pemeringkatan CGPI yang telah didasarkan pada instrumen-instrumen pengukuran GCG yang dikembangkan oleh The Indonesian Institute for Corporate Governance (IICG).

IICG menggunakan tujuh komponen dalam menilai penerapan corporate governance Tujuh komponen tersebut adalah: 1) komitmen terhadap corporate governance, 2) hak pemegang saham, 3) tata kelola dewan komisaris, 4) komitekomite fungsional (yang membantu tata kelola dewan komisaris), 5) direksi, 6) transparansi, dan 7) hubungan dengan stakeholders (Darmawati et al., 2004). Hasil Penilaian CGPI berdasar tujuh komponen tersebut kemudian dikategorisasi untuk tujuan pemeringkatan dan dinilai dengan menggunakan kriteria skor sebagai berikut:
a. Sangat Terpercaya
: Apabila skor CGPI $85-100$
b. Terpercaya
: Apabila skor CGPI 70 - 84
c. Cukup Terpercaya
: Apabila skor CGPI 55 - 69

Data yang terkait penilaian penerapan corporate governance tersebut diperoleh melalui laporan pemeringkatan Corporate Governance Perception Index (CGPI) yang dilakukan oleh The Indonesian Institute for Corporate Governance (IICG).

\section{Model Penelitian}

Data yang telah dikumpulkan kemudian akan dianalisis menggunakan alat bantu analisis statistik regresi linear sederhana dan regresi linear berganda. Pada penelitian ini digunakan elemen manajemen modal kerja sebagai variabel pemoderasi sehingga dalam analisis regresi ditambahkan uji interaksi perkalian antara variabel independen dengan variabel moderasinya dan dengan demikian model-model regresi yang digunakan dalam penelitian ini adalah sebagai berikut:

a. Analisis regresi linier sederhana.

$$
\mathrm{Y}=\alpha+\beta_{1} \mathrm{X}_{1}+\mu_{\mathrm{it}}
$$

b. Model Persamaan Moderated Regression Analysis (MRA).

$$
\mathrm{Y}=\alpha+\beta_{1} \mathrm{X}_{1}+\beta_{2} \mathrm{Z}+\beta_{3} \mathrm{X}_{1} \cdot \mathrm{Z}+\mu_{\mathrm{it}}
$$




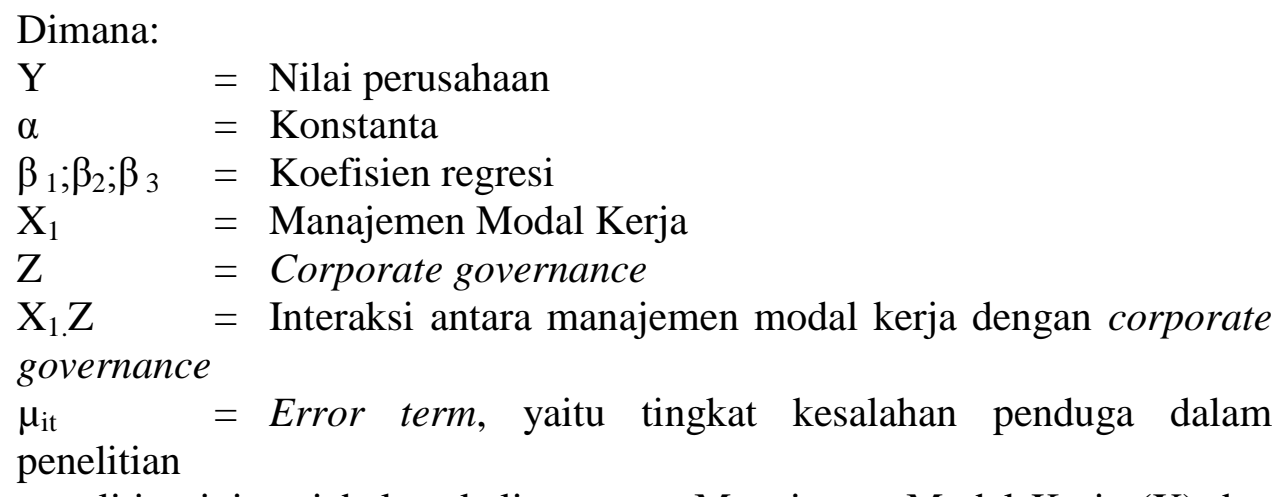

Dalam penelitian ini variabel perkalian antara Manajemen Modal Kerja (X) dan Corporate Governance ( $\mathrm{Z})$ merupakan variabel pemoderasi karena bertujuan untuk menggambarkan pengaruh moderasi (moderating effect) antara variabel Corporate Governance (Z) terhadap hubungan Manajemen Modal Kerja (X) dan Nilai Perusahaan (Y).

\section{HASIL DAN PEMBAHASAN Statistik Deskriptif}

Tabel 1 Output Statistik Deskriptif

\begin{tabular}{lrrrrr}
\hline Variabel & N & Minimum & Maksimum & \multicolumn{1}{c}{ Mean } & Std. Deviation \\
\hline TobinsQ & 93 &, 09 & 3,76 & 1,3570 &, 80283 \\
CCC & 93 & -527 & 1524 & 87,71 & 274,180 \\
CG & 93 & 60,55 & 89,57 & 78,3928 & 6,39556 \\
\hline
\end{tabular}

Berdasarkan pada Tabel 1 di atas menunjukkan bahwa nilai perusahaan yang diukur dengan menggunakan Tobin's Q pada perusahaan sampel memiliki nilai rata-rata (mean) sebesar 1,357. Nilai rata-rata manajemen modal kerja yang diukur dengan menggunakan siklus konversi kas pada perusahaan sampel adalah 87,71 . Nilai tersebut menunjukkan lamanya waktu atau periode yang dibutuhkan oleh perusahaan sampel untuk mengkonversi setiap kas yang dikeluarkan menjadi aliran kas masuk dalam kegiatan operasional perusahaan sehari-hari. Sedangkan nilai rata-rata corporate governance pada perusahaan sampel adalah sebesar 78,3928. Melalui nilai tersebut dapat diketahui bahwa perusahaan sampel telah memiliki tata kelola perusahaan yang baik meliputi struktur, sistem dan proses yang baik sebagai upaya untuk memberikan nilai tambah bagi para stakeholder dan meningkatkan kepercayaan para stakeholder terhadap perusahaan yang bersangkutan.

\section{Hasil Uji Signifikansi Simultan (Uji Statistik F)}

Tabel 2. Hasil Uji F

Persamaan 1

\begin{tabular}{llrrrrr}
\hline Model & & Sum of Squares & df & Mean Square & F & Sig. \\
\hline 1 & Regression & 5,653 & 1 & 5,653 & 9,641 &, $003^{\mathrm{a}}$ \\
& Residual & 50,421 & 86 &, 586 & & \\
& Total & 56,074 & 87 & & & \\
\hline
\end{tabular}


Tabel 3. Hasil Uji F

Persamaan 2

\begin{tabular}{|c|c|c|c|c|c|c|}
\hline Model & & $\begin{array}{l}\text { Sum of } \\
\text { Squares }\end{array}$ & df & Mean Square & $\mathrm{F}$ & Sig. \\
\hline \multirow[t]{3}{*}{1} & Regression & 7,021 & 3 & 2,340 & 4,008 &, $010^{\mathrm{a}}$ \\
\hline & Residual & 49,053 & 84 &, 584 & & \\
\hline & Total & 56,074 & 87 & & & \\
\hline
\end{tabular}

Hasil perhitungan uji F pada Tabel 2 menunjukkan bahwa pada persamaan pertama diperoleh nilai F-hitung sebesar 9,641 dengan probabilitas sebesar 0,003. Sedangkan pada Tabel 3 menunjukkan bahwa pada persamaan kedua diperoleh nilai F-hitung sebesar 4,008 dengan probabilitas sebesar 0,010. Angka probabilitas pada kedua persamaan tersebut lebih kecil dari nilai tingkat signifikansi $0,05(\alpha=5 \%)$, sehingga dapat disimpulkan bahwa model yang digunakan untuk menguji manajemen modal kerja (CCC), corporate governance (CG), nilai perusahaan (Tobin's Q), dan interaksi antara manajemen modal kerja (CCC) dan corporate governance (CG) adalah model yang fit.

\section{Hasil Uji Koefisien Determinasi $\left(\mathbf{R}^{2}\right)$}

\section{Tabel 4}

Koefisien Determinasi $\left(\mathbf{R}^{2}\right)$

Persamaan 1

\begin{tabular}{|c|c|c|c|c|}
\hline & & & Adjusted R & \\
\hline Model & $\mathrm{R}$ & R Square & Square & Std. Error of the Estimate \\
\hline 1 &, $317^{\mathrm{a}}$ & 101 & ,090 & ,76570 \\
\hline
\end{tabular}

Tabel 5

Koefisien Determinasi $\left(\mathbf{R}^{2}\right)$

Persamaan 2

\begin{tabular}{|c|c|c|c|c|}
\hline & & & Adjusted R & \\
\hline Model & $\mathrm{R}$ & R Square & Square & Std. Error of the Estimate \\
\hline 1 &, $354^{\mathrm{a}}$ &, 125 & ,094 & ,76417 \\
\hline
\end{tabular}

Uji Signifikansi Parameter Individual (Uji t)

Tabel 6

Hasil Uji t

Persamaan 1 (Parsial)

\begin{tabular}{|c|c|c|c|c|c|c|}
\hline \multirow[b]{2}{*}{ Model } & & \multicolumn{3}{|r|}{$\begin{array}{l}\text { Standardized } \\
\text { Coefficients }\end{array}$} & \multirow[b]{2}{*}{$\mathrm{t}$} & \multirow[b]{2}{*}{ Sig. } \\
\hline & & B & Std. Error & Beta & & \\
\hline 1 & (Constant) & 1,276 &, 086 & & 14,876 &, 000 \\
\hline & $\mathrm{CCC}$ &, 001 & ,000 & ,317 & 3,105 & ,003 \\
\hline
\end{tabular}




\section{Tabel 7}

Hasil Uji t

Persamaan 2 (Moderasi)

\begin{tabular}{llrrrrr}
\hline & & \multicolumn{5}{c}{ Standardized } \\
Mnstandardized Coefficients & \multicolumn{2}{c}{ Coefficients } & & \\
\cline { 3 - 5 } Model & & \multicolumn{1}{c}{ B } & \multicolumn{1}{c}{ Std. Error } & Beta & \multicolumn{1}{c}{ S } & \multicolumn{1}{c}{ Sig. } \\
\hline 1 & (Constant) &, 235 & 1,017 & &, 231 &, 818 \\
& CCC &,- 004 &, 005 & $-1,340$ &,- 803 &, 424 \\
& CG &, 013 &, 013 &, 106 & 1,030 &, 306 \\
& Moderasi & $6,207 \mathrm{E}-5$ &, 000 & 1,664 &, 998 &, 321 \\
\hline
\end{tabular}

Berdasarkan hasil perhitungan uji $\mathrm{t}$ pada Tabel 6 diketahui bahwa Manajemen Modal Kerja (CCC) memiliki pengaruh positif terhadap Nilai Perusahaan. Sedangkan pada Tabel 7 dapat diketahui bahwa nilai t-hitung untuk variabel moderasi sebesar 0,998 dengan signifikansi sebesar 0,321. Nilai signifikansi yang lebih besar dari tingkat signifikansi $0,05(\alpha=5 \%)$ menunjukkan bahwa variabel Corporate Governance tidak mampu memengaruhi atau memoderasi hubungan antara Manajemen Modal Kerja (CCC) dengan Nilai Perusahaan (Tobin's Q).

\section{Analisis Regresi}

Penelitian ini menggunakan metode regresi linier sederhana dan metode Moderated Regression Analysis (MRA). Hasil analisis regresi dalam penelitian ini dapat dilihat pada tabel berikut:

Tabel 8

Hasil Regresi Linier Sederhana Persamaan 1 (Parsial)

\begin{tabular}{|c|c|c|c|c|c|c|}
\hline \multirow{2}{*}{\multicolumn{2}{|c|}{ Model }} & \multicolumn{2}{|c|}{$\begin{array}{l}\text { Unstandardized } \\
\text { Coefficients }\end{array}$} & \multirow{2}{*}{$\begin{array}{c}\text { Standardized } \\
\text { Coefficients } \\
\text { Beta }\end{array}$} & \multirow[b]{2}{*}{$\mathrm{t}$} & \multirow[b]{2}{*}{ Sig. } \\
\hline & & B & Std. Error & & & \\
\hline \multirow[t]{2}{*}{1} & (Constant) & 1,276 &, 086 & & 14,876 &, 000 \\
\hline & $\mathrm{CCC}$ & ,001 & ,000 & 317 & 3,105 & ,003 \\
\hline
\end{tabular}

Tabel 9

Hasil Regresi Moderated Regression Analysis (MRA) Persamaan 2 (Moderasi)

\begin{tabular}{|c|c|c|c|c|c|c|}
\hline \multirow{2}{*}{\multicolumn{2}{|c|}{ Model }} & \multicolumn{2}{|c|}{$\begin{array}{c}\text { Unstandardized } \\
\text { Coefficients }\end{array}$} & \multirow{2}{*}{$\begin{array}{c}\text { Standardized } \\
\text { Coefficients } \\
\text { Beta }\end{array}$} & \multirow[b]{2}{*}{$\mathrm{t}$} & \multirow[b]{2}{*}{ Sig. } \\
\hline & & $\mathrm{B}$ & Std. Error & & & \\
\hline \multirow[t]{4}{*}{1} & (Constant) & ,235 & 1,017 & & 231 &, 818 \\
\hline & $\mathrm{CCC}$ &,- 004 &, 005 & $-1,340$ &,- 803 & ,424 \\
\hline & $\mathrm{CG}$ &, 013 & ,013 & ,106 & 1,030 & ,306 \\
\hline & Moderasi & $6,207 \mathrm{E}-5$ & ,000 & 1,664 & ,998 & ,321 \\
\hline
\end{tabular}

\section{Pengaruh Manajemen Modal Kerja terhadap Nilai Perusahaan}

Hasil penelitian ini menunjukkan bahwa manajemen modal kerja yang diukur melalui siklus konversi kas memiliki pengaruh yang positif terhadap nilai 
perusahaan. Hasil penelitian ini sesuai dengan konsep manajemen modal kerja, di mana perusahaan dengan penerapan manajemen modal kerja yang baik akan memiliki tingkat likuiditas yang tinggi dan profitabilitas yang tinggi. Secara lebih rinci, melalui kebijakan manajemen modal kerja yang efisien berarti perusahaan menerapkan siklus konversi kas yang singkat yang mana berasosiasi dengan penurunan waktu konversi persediaan, percepatan waktu penagihan piutang kepada pelanggan, dan penundaan pembayaran utang kepada kreditur (Nobanee, 2009). Perusahaan dengan pengelolaan modal kerja yang efisien pada akhirnya akan dapat menciptakan suatu nilai tambah (value added) bagi para pemegang saham dan merangsang para investor di pasar untuk berinvestasi pada perusahaan yang bersangkutan.

Syarief dan Wilujeng (2009) juga menjelaskan bahwa fenomena peningkatan profitabilitas perusahaan melalui siklus konversi kas yang singkat dapat terjadi karena perusahaan dengan jangka waktu siklus konversi kas (cash conversion cycle/CCC) yang singkat mampu mengumpulkan kas yang diperlukan untuk kegiatan operasional sehari-hari perusahaan dengan lebih cepat. Implikasinya adalah bahwa perusahaan tidak perlu memakai maupun mencari tambahan sumber pendanaan yang berasal dari luar perusahaan. Ketika perusahaan tidak membutuhkan pendanaan tambahan dari pihak lain maka hal itu berarti tidak ada tambahan biaya yang harus dikeluarkan untuk pinjaman dana, sehingga selanjutnya keuntungan perusahaan akan dapat meningkat.

Pada saat profitabilitas perusahaan mengalami peningkatan, tidak menutup kemungkinan bahwa jumlah dividen yang diterima oleh para pemegang saham juga akan mengalami peningkatan. Adanya peningkatan dalam jumlah dividen mengindikasikan bahwa tingkat kesejahteraan pemegang saham perusahaan semakin tinggi dan pada akhirnya perusahaan yang bersangkutan akan memiliki nilai perusahaan yang tinggi di mata investor. Harga saham perusahaan yang memiliki nilai perusahaan yang tinggi biasanya akan mengalami kenaikan karena investor di pasar menilai perusahaan yang bersangkutan memiliki prospek yang baik dan masih dapat terus bertahan (sustainable) di masa depan.

\section{Pengaruh Corporate Governance sebagai Variabel Pemoderasi dalam Hubungan antara Manajemen Modal Kerja dengan Nilai Perusahaan}

Pengujian yang dilakukan terhadap variabel corporate governance yang merupakan variabel pemoderasi dalam penelitian ini menunjukkan hasil bahwa variabel corporate governance tidak dapat memengaruhi hubungan antara manajemen modal kerja terhadap nilai perusahaan. Hal itu berarti bahwa manajemen modal kerja tidak dapat meningkatkan nilai perusahaan pada saat tingkat penerapan konsep corporate governance tinggi, dan sebaliknya manajemen modal kerja juga tidak dapat menurunkan nilai perusahaan pada saat tingkat penerapan konsep corporate governance rendah.

Hasil negatif tersebut terjadi karena masih kurangnya kepedulian dan respon investor yang ada di Indonesia terhadap penerapan konsep corporate governance. Hal itu pada akhirnya juga menyebabkan keikutsertaan perusahaanperusahaan publik dalam program pemeringkatan Corporate Governance Perception Index (CGPI) yang diselenggarakan oleh The Indonesian Institute for Corporate Governance (IICG) tidak mampu memengaruhi peningkatan nilai 
perusahaan yang bersangkutan. Di samping itu, aspek penilaian dalam program pemeringkatan Corporate Governance Perception Index (CGPI) juga dimungkinkan menyebabkan variabel corporate governance dalam penelitian ini tidak dapat memperkuat maupun memperlemah hubungan antara manajemen modal kerja dan nilai perusahaan. Hal itu terjadi karena program pemeringkatan Corporate Governance Perception Index (CGPI) yang diselenggarakan oleh The Indonesian Institute for Corporate Governance (IICG) mempunyai tema yang berbeda-beda setiap tahunnya sehingga meskipun kategori penilaiannya tetap sama, akan tetapi sub kategori yang menjadi pedoman dalam aspek penilaian tersebut berbeda-beda mengikuti tema pada tahun yang bersangkutan. Pada akhirnya perbedaan itu yang mengakibatkan hasil penilaian corporate governance berbeda setiap tahunnya.

Corporate governance yang diukur melalui indeks corporate governance dalam program pemeringkatan Corporate Governance Perception Index (CGPI) yang diselenggarakan oleh The Indonesian Institute for Corporate Governance (IICG) masih kurang dipercaya oleh sebagian besar perusahaan dan investor di pasar modal. Hal itu dikarenakan pembobotan dan penilaian penerapan prinsipprinsip corporate governance dalam perusahaan yang dilakukan oleh IICG hanya berdasarkan pada kuesioner dan wawancara, sehingga tingkat validitas dan reliabilitasnya dapat dikatakan masih kurang. Sebagai contoh, dalam hal penilaian pengungkapan laporan keuangan (disclosure) pihak IICG memberikan penilaian yang sama terhadap kuesioner yang digunakan sehingga tidak terdapat perbedaan penilaian antara perusahaan yang mengungkapkan laporan keuangannya secara lengkap dan perusahaan yang mengungkapkan hanya sebagian atau tidak lengkap.

\section{SIMPULAN DAN KETERBATASAN PENELITIAN}

\section{Simpulan}

Berdasarkan hasil penelitian di atas maka dapat dismpulkan bahwa:

1) Manajemen modal kerja yang diukur melalui siklus konversi kas mampu secara signifikan memengaruhi nilai perusahaan. Hal ini mengindikasikan bahwa perusahaan yang berhasil memilih dan menerapkan konsep manajemen modal kerja yang tepat serta sesuai dengan karakteristik perusahaan maka pencapaian peningkatan profitabilitas pada perusahaan yang bersangkutan dapat dengan mudah dilakukan, sehingga pada akhirnya juga akan memengaruhi peningkatan pada harga saham dan nilai perusahaan.

2) Corporate governance tidak mampu memoderasi pengaruh antara manajemen modal kerja terhadap nilai perusahaan. Hal itu berarti manajemen modal kerja tidak mampu meningkatkan nilai perusahaan pada saat tingkat penerapan konsep corporate governance tinggi, dan sebaliknya manajemen modal kerja juga tidak mampu menurunkan nilai perusahaan pada saat tingkat penerapan konsep corporate governance rendah.

\section{Keterbatasan Penelitian}

Penelitian ini memiliki beberapa keterbatasan yang dapat digunakan sebagai bahan pertimbangan bagi peneliti berikutnya sehingga mendapatkan hasil penelitian yang lebih baik. Adapun keterbatasan yang ada dalam penelitian ini adalah sebagai berikut: 
1) Variabel corporate governance yang diukur melalui peringkat program Corporate Governance Index (CGPI) yang dilaksanakan oleh The Indonesian Institute for Corporate Governance gagal memoderasi pengaruh manajemen modal kerja terhadap nilai perusahaan. Hal itu dikarenakan tidak semua perusahaan dan investor di Indonesia percaya terhadap hasil pemeringkatan program tersebut sehingga sebaiknya penelitian berikutnya dapat membuat suatu indeks tersendiri guna menilai penerapan prinsip-prinsip corporate governance dalam perusahaan. Melalui indeks baru tersebut diharapkan penilaian terhadap corporate governance menjadi lebih representatif dan dapat secara tepat menggambarkan keadaan yang sesungguhnya.

2) Dalam penelitian ini metode regresi yang digunakan untuk memprediksi pengaruh variabel moderator terhadap persamaan utama adalah Moderated Regression Analysis (MRA) sehingga hal ini akan menyebabkan terjadinya tingkat multikolinieritas yang tinggi dan hasil penelitian menjadi kurang sempurna. Pada penelitian berikutnya diharapkan dapat menggunakan metode regresi selain MRA yaitu metode Uji Nilai Residual dalam memprediksi pengaruh variabel moderator sehingga diharapkan hasil penelitian dapat menjadi lebih baik. 


\section{DAFTAR PUSTAKA}

Azhar, Nor Edi dan Noriza. 2010. 'Working Capital Management: The Effect of Market Valuation and Profitability in Malaysia', International Journal of Business and Management, Vol. 5, No. 11, November 2010, hal. 140-147.

Bandara dan Weerakoon Banda Y.K. 2011. 'Impact of Working Capital Management Practice on Firm Value', Working Paper.

Bauer, Rob, Nadja Guenster, dan Roger Otten. 2003. 'Empirical Evidence on Corporate Governance in Europe: The Effect on Stock Returns, Firm Value and Performance', Journal of Asset Management, Vol. 5, No. 2, hal. 91-104

Black, Bernard S. 2001. 'The Corporate Governance Behavior and Market Value of Russian Firms', Emerging Markets Review, Vol. 2, Maret 2001, hal. 125.

Black, Bernard S., Inessa Love dan Andrei Rachinsky. 2005. 'Corporate Governance and Firms' Market Values: Time Series Evidence from Russia', Working Paper, European Corporate Governance Institute, November 2005, hal. 1-40.

Black, Bernard S., Hasung Jang, dan Woochan Kim. 2006. 'Does Corporate Governance Predict Firms' Market Values? Evidence from Korea', The Journal of Law, Economics, \& Organization, Vol. 22, No. 2, hal. 366-413.

Deloof, Marc. 2003. 'Does Working Capital Management Affect Profitability of Belgian Firms?', Journal of Business, Finance, and Accounting, Vol. 30, No. 3 dan 4, April/May 2003, hal. 573-587.

Ergin, Emre. 2012. 'Corporate Governance Ratings and Market-based Financial Performance: Evidence from Turkey', International Journal of Economics and Finance, Vol. 4, No. 9, 2012, hal. 61-68.

Ganesan, Vedavinayagam. 2007. 'An Analysis of Working Capital Management Efficiency in Telecommunication Equipment Industry', Rivier Academic Journal, Vol. 3 No. 2, Fall 2007, hal. 1-10.

Gill, Amarjit S. dan John D. Obradovich. 2012. 'The Impact of Corporate Governance and Financial Leverage on the Value of American Firms', International Research Journal of Finance and Economics, Issue 91, hal. 114.

Gill, Amarjit S. dan Nahum Biger. 2013. 'The Impact of Corporate Governance on Working Capital Management Efficiency of American Manufacturing Firms', Managerial Finance, Vol. 39, Issue 2 hal. 116-132.

Harford, J., Mansi, S.A. dan Maxwell, W.F. 2008. 'Corporate Governance and Firm Cash Holdings in the US', Journal of Financial Economics, Vol. 87 No. 3, hal. 535-555.

Klapper, Leora F. dan Inessa Love. 2002. 'Corporate Governance, Investor Protection, and Performance in Emerging Markets', World Bank Policy Research Working Paper No. 2818, April 2002, hal. 1-40.

Nobanee, Haitham. 2009. 'Working capital management and Firm's Profitability: An Optimal Cash Conversion Cycle', Working Paper.

Ogundipe, Lawrencia Olatunde, Sunday. E. Ogundipe, dan Abiola Idowu. 2012. 'Working Capital Management, Firms' Performance and Market Valuation in Nigeria', International Journal of Social and Human Sciences, Vol. 6, 2012, hal. 143-147. 
Sharma, A.K. dan Satish Kumar. 2011. 'Effect of Working Capital Management on Firm Profitability', Global Business Review, Vol. 12, No. 1, hal 159173.

Sudana, I Made. 2011. Manajemen Keuangan Perusahaan; Teori dan Praktik. Jakarta: Erlangga.

Syarief, Moch. Edman dan Ita Prihatining Wilujeng. 2009. 'Cash Conversion Cycle dan Hubungannya dengan Ukuran Perusahaan, Profitabilitas, dan Manajemen Modal Kerja', Jurnal Ekonomi dan Bisnis, Tahun 14, No. 1, Maret 2009, hal. 61-69.

Verlyn D., Richard dan Eugene J. Laughlin. 1980. 'A Cash Conversion Cycle Approach to Liquidity Analysis', Financial Management, Vol. 9, No. 1 (Spring, 1980), hal. 32-38. 